Popular Summary

Glacier Ice Mass Fluctuations and Fault Instability in Tectonically Active Southern Alaska by Jeanne M. Sauber and Bruce F. Molnia

Across southern Alaska the northwest directed subduction of the Pacific plate is accompanied by accretion of the Yakutat terrane to continental Alaska. This has led to high tectonic strain rates and dramatic topographic relief of more than 5000 meters within $15 \mathrm{~km}$ of the Gulf of Alaska coast. The glaciers of this area are extensive and include large glaciers undergoing wastage (glacier retreat and thinning) and surges. The large glacier ice mass changes perturb the tectonic rate of deformation at a variety of temporal and spatial scales. We estimated surface displacements and stresses associated with ice mass fluctuations and tectonic loading by examining GPS geodetic observations and numerical model predictions. Although the glacial fluctuations perturb the tectonic stress field, especially at shallow depths, the largest contribution to ongoing crustal deformation is horizontal tectonic strain due to plate convergence. Tectonic forces are thus the primary force responsible for major earthquakes. However, for geodetic sites located < $10-20 \mathrm{~km}$ from major ice mass fluctuations, the changes of the solid Earth due to ice loading and unloading are an important aspect of interpreting geodetic results.

The ice changes associated with Bering Glacier's most recent surge cycle are large enough to cause discenible surface displacements. Additionally, ice mass fluctuations associated with the surge cycle can modify the short-term seismicity rates in a local region. For the thrust faulting environment of the study region a large decrease in ice load may cause an increase in seismic rate in a region close to failure whereas ice loading may inhibit thrust faulting.

Prior to the 1979 St. Elias earthquake $(M=7.2)$, the main thrust zone below the study region had been locked since the 1899 earthquakes and strain had been accumulating. During this same time period ongoing wastage of southern Alaska glaciers was 100's of meters up to almost a $1 \mathrm{~km}$. We used estimates of ice thickness decrease to calculate the changes in the fault stability margin around the region of the 1979 St. Elias earthquake and aftershocks. Our results suggest that the cumulative decrease in the fault stability margin due to ice wastage between 1899 and 1979 was large and would promote thrust faulting. Since earthquake hazard evaluations are based on the paleoseismic history of the region, for glaciated areas the concurrent glacial history should be considered in this evaluation. 


\section{Glacier Ice Mass Fluctuations and Fault Instability in Tectonically Active Southern Alaska}

Jeanne M. Sauber, Geodynamics Branch, Laboratory for Terrestrial Physics, NASA's Goddard Space Flight Center, MD, 20771, USA ${ }^{1}$

Bruce F. Molnia, Earth Surface Processes Team, U.S. Geological Survey, 926A National Center, Reston, VA, 20192, USA ${ }^{2}$

\section{Abstract}

Across the plate boundary zone in south central Alaska tectonic strain rates are high in a region that includes large glaciers undergoing wastage (glacier retreat and thinning) and surges. For the coastal region between the Bering and Malaspina Glaciers the average ice mass thickness changes between 1995 and 2000 range from 1-5 m/yr. These ice changes caused solid Earth displacements in our study region with predicted values of $-10 \mathrm{~mm}$ to $50 \mathrm{~mm}$ in the vertical and predicted horizontal displacements of 0 $10 \mathrm{~mm}$ at variable orientations. Relative to stable North America, observed horizontal rates of tectonic deformation range from $10-40 \mathrm{~mm} / \mathrm{yr}$ to the north-northwest and the predicted tectonic uplift rates range from approximately $0 \mathrm{~mm} / \mathrm{yr}$ near the Gulf of Alaska coast to $12 \mathrm{~mm} / \mathrm{yr}$ further inland. The ice mass changes between 1995-2000 resulted in discernible changes in the GPS measured station positions of one site (ISLE) located adjacent to the Bagley Ice Valley and at one site, DON, located south of the Bering Glacier terminus. In addition to modifying the surface displacements rates, we evaluated

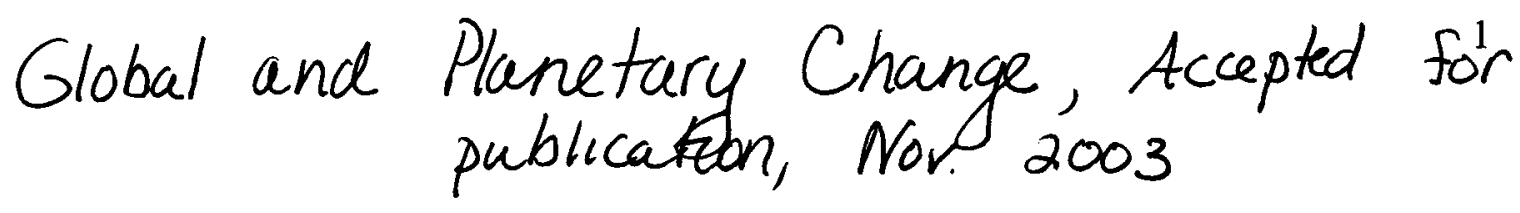


the influence ice changes during the Bering glacier surge cycle had on the background seismic rate. We found an increase in the number of earthquakes $\left(M_{L} \geq 2.5\right)$ and seismic rate associated with ice thinning and a decrease in the number of earthquakes and seismic rate associated with ice thickening. These results support the hypothesis that ice mass changes can modulate the background seismic rate.

During the last century, wastage of the coastal glaciers in the Icy Bay and Malaspina region indicates thinning of hundreds of meters and in areas of major retreat, maximum losses of ice thickness approaching $1 \mathrm{~km}$. Between the 1899 Yakataga and Yakutat earthquakes $\left(M_{w}=8.1,8.1\right)$ and prior to the 1979 St. Elias earthquake $\left(M_{s}=\right.$ 7.2), the plate interface below Icy Bay was locked and tectonic strain accumulated. We used estimated ice mass change during the 1899 - 1979 time period to calculate the change in the fault stability margin prior to the 1979 St. Elias earthquake. Our results suggest that a cumulative decrease in the fault stability margin at seismogenic depths, due to ice wastage over 80 years, was large, up to $\sim 2 \mathrm{MPa}$. Ice wastage would promote thrust faulting in events such as the 1979 earthquake and subsequent aftershocks.

${ }^{1}$ Corresponding author;phone:301-614-6465;FAX:301-614-6522;email:Jeanne.M.SauberRosenberg@nasa.gov

2phone:703-648-4120; FAX: 703-648-6953; email: bmolnia@usgs.gov

Key Words: Postglacial Rebound, Stress Fields, Induced Earthquakes, Alaska, Subduction Zones, GPS, Glaciers 


\section{Introduction}

Across southern Alaska the northwest directed subduction of the Pacific plate, $v_{p}$ $=53 \mathrm{~mm} / \mathrm{yr}$ [DeMets et al., 1994], is accompanied by accretion of the Yakutat terrane to continental Alaska $\left(v_{a c c r}=33-44 \mathrm{~mm} / \mathrm{yr}\right)$ [Plafker et al., 1994]. This has led to high tectonic strain rates and dramatic topographic relief of more than 5000 meters within 15 $\mathrm{km}$ of the Gulf of Alaska coast. The glaciers of this area are extensive (Figure 1) and many of them have undergone significant advances and retreats of kilometers to tens of kilometers on time scales ranging from decades to thousands of years [Molnia, 2003]. The repeat times of large earthquakes in this region are hundreds of years [Nishenko and $J a c o b, 1990]$.

In Scandinavia and interior Canada the tectonic deformation rates are low but the change in glacier thickness during late Pleistocene deglaciation were large (up to $\sim 3 \mathrm{~km}$ ) over regional to continental spatial scales. During and following late Pleistocene deglaciation moderate earthquakes occurred in the stable interior of Canada but large earthquakes occurred in Scandinavia (see summary and papers in topical volume Stewart et al., 2000). In southern Alaska tectonic deformation rates are high but the recent change in ice load is smaller $(<1 \mathrm{~km})$ and local to regional in extent. Our data suggest that fluctuation of Alaska glaciers over the last 100 years may influence the timing of southern Alaska earthquakes, but tectonic forces largely control the rate and distribution of ongoing crustal deformation. 
In this study we present new estimates of the surface displacements associated with ice mass changes following the 1993-1995 Bering glacier surge (1995-2000) and we evaluate the influence that associated stress changes may have on the background seismic rate. Also, we use an estimate of the cumulative ice thickness decrease between 1899 and 1979 to calculate predicted stress changes along the main thrust zone that slipped in the 1979 St. Elias earthquake $\left(M_{s}=7.2\right)$.

Although glacial, sedimentary, and tectonic processes in southern Alaska have been well studied significant questions remain to be answered [Jaeger et al., 2001]. Specifically in this study, we address in Section 2 "How large are recent ice mass fluctuations between the Malaspina and Bering Glaciers"? Then in Section 3, "What are the tectonic displacement rates and stresses"? Followed by, "How do we quantify the influence of ice mass changes on earthquake faulting?" in Section 4. Next, in Section 5 we address, "What are surface displacement changes and incremental stresses associated with recent ice mass fluctuations?" and "Do these ice mass fluctuations alter the seismic rate of background seismicity?" Finally, in Section 6 we ask, "What influence could ice mass changes have had on large earthquakes in the Icy Bay region?"

\section{Glacier Ice Mass Fluctuations in Alaska}

The last major glaciation episode in Alaska is correlated with late Wisconsin fluctuations of the Laurentide Ice Sheet. Radiocarbon ages show onset of glaciation at 24 Kyr BP, peak glaciation at $18 \mathrm{Kyr} \mathrm{BP}$, deglaciation beginning at about $13.5 \mathrm{Kyr} \mathrm{BP}$, and retreat from the continental shelf complete by about $10 \mathrm{Kyr}$ BP [Molnia, 1989; Hamilton, 1994]. The ICE-4G ice-unloading model includes a simple representation of Alaskan 
deglaciation [Peltier, 1993, 1994]. The ICE-4G predicted uplift caused by late Pleistocene deglaciation was about $2 \mathrm{~mm} / \mathrm{yr}$ near VYAK (Figure 2). An asthenosphere viscosity less than $10^{20} \mathrm{~Pa} \mathrm{~s}$ inferred from post-glacial rebound studies in southern Alaska [Sauber et al,. 2000; Larsen et al., 2003; Tamisiea et al., 2003], as well as other subduction zones [Ivins and James, 1999; James et al., 2000], is lower than the viscosity derived from global postglacial rebound studies. In southern Alaska relaxation times would be $<100$ years. Therefore, the ongoing uplift due to late Pleistocene deglaciation is probably smaller than suggested by the ICE- $4 \mathrm{G}$ model because most of the rebound would have occurred much earlier.

Following late Pleistocene deglaciation, additional large glacier ice fluctuations that were either regional or global (Little Ice Age) in extent have been suggested. A major regional glacier ice advance, widely documented in Alaska, culminated 2600 to 2800 years ago throughout the Cordilleran region [Porter and Denton, 1967]. It is interesting to note that the age of marine terrace $\Pi$ in the Icy Bay region (Figure 1) has a midrange calendar age of 2533 yr BP [Plafker et al., 1981; Sauber et al., 2000]. A long period of milder climate followed in which glacier volume and extent significantly diminished. The next major documented regional advance occurred during the Little Ice Age.

As summarized by Molnia[2003], during the Little Ice Age the area of glacier coverage was at least $10 \%$ greater than the ice today. Retreat from the Little Ice Age maximum position and thinning began as early as the first half of the eighteenth century (pre-1750) in the southeastern Alaska Coast Mountains. In the Chugach-St. Elias Mountains region retreat generally began later (post-1850) and today more than $95 \%$ of 
the glaciers extending below $1500 \mathrm{~m}$ are currently undergoing thinning, retreat, and or stagnation.

\subsection{Surge-Retreat Cycle of Bering Glacier, Alaska in the Last 100 Years}

A significant retreat of the Bering Glacier began sometime between 1905 and 1910 [Molnia and Post, 1995]. The recession of the Bering Glacier has been interrupted by at least six twentieth century surges [Molnia and Post, 1995; Muller and Fleisher, 1995]. A surging glacier develops a periodically oscillating state characterized by a long period of slow build-up of ice in the middle and upper parts of the glacier with retreat in the terminus region (intersurge or "quiescent phase" of Bindschadler, 1982), followed by a surge [Budd and McInnes, 1974; Kamb et al., 1985]. During a surge, ice is transported from the upper reaches (the surge "reservoir" region) of the glacier, its surface locally lowers by tens of meters as the ice is transported down glacier, where the glacier thickens and the terminus frequently advances (the surge "receiving" region).

During the 1993-1995 Bering Glacier surge, a large transfer of ice from the Bagley Ice Valley to the Bering Glacier terminus region occurred. The results of extensive efforts to study the 1993-1995 Bering Glacier surge have provided some constraints on its timing, spatial extent, and ice thickness changes [Lingle et al., 1993; Molnia, 1993; Krimmel, 1994; Molnia et al., 1994; Molnia and Post, 1995; Sauber et al., 1995, 2000; Roush, 1996; Herzfeld and Mayer, 1997; Fatland, 1998; Fatland and Lingle, 1998; Molnia, 2003]. Earlier, Sauber et al. [1995, 2000] calculated the elastic displacement of the solid Earth due to ice mass changes during the surge and compared them to Global Positioning System (GPS) measurements at sites near the Bering Glacier. 
Since the cessation of terminus advance in mid-September 1995, the Bering Glacier returned to actively thinning and retreating. Between 1995 and 2003 the terminus of the Bering Glacier lobe has retreated up to $6.5 \mathrm{~km}$ and the maximum surface thinning in the piedmont lobe exceeded $100 \mathrm{~m}$. Based on repeated aircraft laser profiles along a centerline profile, Arendt et al., [2002] estimated an average yearly thinning rate for Bering Glacier's piedmont lobe of $3.1 \mathrm{~m} / \mathrm{yr}$ between 1995 and 2000. During the latter part of the $20^{\text {th }}$ century, parts of the Bering Glacier's piedmont lobe thinned $>5 \mathrm{~m} / \mathrm{yr}$ [Molnia and Post, 1995; Molnia, 2003].

Following the surge, in the surge reservoir region, transport of ice from upstream in the eastern Bagley Ice Valley has resulted in a thickening of ice near GPS site ISLE (Figure 1). Field observations made in August 2000 by B. Molnia suggest that between 1997 and 2000, in the region south and east of ISLE, the glacier ice thickened by 10-20 meters while immediately north of the station ISLE, the Jefferies and Tana Glaciers have thinned by $1-3 \mathrm{~m} / \mathrm{yr}$. The Jefferies and Tana Glaciers were not affected by the Bering Glacier surge.

\subsection{Glaciers of Icy Bay and the Malaspina Glacier}

The present Icy Bay is the result of twentieth century retreat of ice mass that filled the basin (Molnia, 1977, 1989; Porter, 1989; summary in Molnia, 2003). At the onset of the twentieth century an expanded Guyot-Malaspina Glacier that extended several kilometers into the Gulf of Alaska filled the entire basin. Retreat began prior to 1910 and continues today. During the twentieth century, the glaciers that filled Icy Bay have retreated to form an approximately $40 \mathrm{~km}$ long, triangular-shaped bay, with four separate fiord arms 
at its head (Figure 1). Porter [1989] calculated that the mean rate of retreat in Icy Bay was $\sim 1 \mathrm{~km} / \mathrm{yr}$ for the period 1904 to 1926 and $\sim 0.4 \mathrm{~km} / \mathrm{yr}$ for the period 1926 to 1989 .

Elevations of recent glacial deposits, moraines, and trimlines, show that in many recently deglacierized areas of Icy Bay, former ice thicknesses were significantly greater than $300 \mathrm{~m}$ above m.s.l. (see Table 3, Sauber et al., 2000). Near the present location of the terminus of Tyndall Glacier (Figure 1), the 1959 USGS 1:250,000-scale topographic map [USGS, 1983], which was based on 1957 aerial photography, shows $>800 \mathrm{~m}$ of glacier ice above sea level at a location that presently is ice free. Several hundred meters of ice were also lost from below sea level. Since the early twentieth century, when retreat began in Icy Bay, the maximum ice thinning in parts of the bay has exceeded a kilometer. Although terminus retreat began around 1910, ice wastage in the form of ice thinning probably began sooner.

During most of the twentieth century, the margin of the Malaspina Glacier has been stagnating, down wasting, and retreating. Thinning of the piedmont lobe has been estimated to be 85 to $129 \mathrm{~m}$ in the last 100 years (Sharp, 1961, Lingle et al. 1999; Tangborn, 1999;summary in Molnia, 2003). Aircraft laser altimetry measurements by Arendt et al. [2002] between 1995 and 2000 indicate an average thinning rate of approximately $0.9 \mathrm{~m} / \mathrm{yr}$ across the Malaspina piedmont lobe.

\section{Tectonic Stress and Strain Orientation and Magnitude}

The ongoing rate of tectonic deformation over the last 20 years has been estimated from trilateration, very-long-baseline interferometry (VLBI) and GPS measurements [Savage and Lisowski, 1988; Ma et al., 1990; Sauber et al., 1993, 1997, 2000]. The rate 
and orientation of tectonic stress and strain is due primarily to subduction of the Pacific plate and collision of the Yakutat terrane with interior Alaska (Figure 2). Within the data uncertainties, the VLBI measurements (1984-1990) at Cape Yakataga (VYAK in Figure 2) show a constant velocity for all three components (North, East, and Up) except for an offset due to the $1987 / 1988$ Gulf of Alaska earthquakes. In the next section we discuss the recent (1993-2001) GPS measurements as well as a summary of our numerical modeling of the tectonic component of the surface velocities.

\subsection{Ongoing Tectonic Displacement Rates Across the Study Region}

GPS measurements were made between 1993 and 2000 across a portion of southern Alaska (Figure 2). The GPS data were processed using the GAMIT/GLOBK software [King and Bock, 1997; Herring, 1997]. Details of observations made in 1993, 1995 and 1997 are given in Sauber et al. [1997; 2000]. Subsequently, in August 2000, we conducted a photo-survey of the Bering Glacier and lower reaches of the Bagley Ice Valley to estimate ice thickness change and we made GPS observations at stations ISLE and DON (Figure 2). The horizontal velocities for the full time period were estimated relative to an ITRF2000 North America fixed reference frame (Table 1, Figure 2). We used an approach similar to that discussed by Sauber et al. [2000] to estimate the station velocities. To illustrate the evolution in the time series of measurements at DON and ISLE, we estimated station position for each observation year as well.

Relative to stable North America, the measured horizontal rates of tectonic deformation across the region given in Figure 2 are $10-40 \mathrm{~mm} / \mathrm{yr}$. The predicted tectonic uplift rates range from approximately $0 \mathrm{~mm} / \mathrm{yr}$ near the Gulf of Alaska coast to $12 \mathrm{~mm} / \mathrm{yr}$ 
further inland. The observed uplift rates are significantly higher at some stations and in part reflect uplift associated with either glacial wastage or the Bering Glacier surge cycle.

We used a two-dimensional plane strain finite element method (TECTON, Melosh and Raefsky, 1981) to model the tectonic deformation rates. The finite element grid across this subduction zone plate boundary was modified from Cohen [1996] and includes a shallow dipping subducting slab and both an oceanic crust-mantle and a continental crust-mantle (see Figure 5 in Sauber et al. 2000). The horizontal velocities of sites located $>20 \mathrm{~km}$ from major glacier fluctuations are consistent with a model that includes the viscoelastic response to a downgoing Pacific plate that is locked at shallow depths as well as a component of slip $(15 \mathrm{~mm} / \mathrm{yr})$ perpendicular to the orientation of plate convergence [Sauber et al., 1997, 2002]. Variations in the surface deformation rate due to the viscoelastic response to major earthquakes, as well as downdip creep below the seismogenic zone, may contribute as well. However, until we obtain more permanent GPS sites in this region it is difficult to isolate these contributions.

\subsection{Stress State and Principal Stress Directions}

A number of large earthquakes have occurred in the last 30 years within or near the study region given in Figure 1 and 2 (1970, Pamplona zone $M_{w}=6.7 ; 1979$, St. Elias, $M_{s}$ $=7.2 ; 1987-1988$, Gulf of Alaska, $M_{s}=6.9,7.6,7.6$, Figure 2). The static stress drop for these events ranges from moderate to high ( $\sim 2$ to $10 \mathrm{MPa})$ [Hwang and Kanamori, 1992; Estabrook et al., 1992; Sauber et al., 1993; Doser et al., 1997]. Although stress levels on individual faults are highly variable, these earthquakes suggest that much of the region given in Figure 1 is close to failure. 
The earthquake focal mechanisms, offshore in situ borehole measurements and regional geological evidence [Hottman et al., 1979, Estabrook and Jacob, 1991; Plafker et al., 1994; Doser et al., 1997] have been used to estimate stress directions. For the coastal region between Icy Bay and Cordova (CRDC in Figure 2), a horizontal northsouth to northwest-southeast orientation is suggested for the maximum stress $\left(\sigma_{1}\right)$; east of Icy Bay $\sigma_{1}$ may rotate to more northeast-southwest orientation. A minimum stress, $\sigma_{3}$, that is vertical has been assumed for the dominantly thrust faulting environment. Strikeslip faulting associated with a vertical intermediate stress has been suggested near the Contact fault just north of the Bagley Ice Valley [Savage and Lisowski, 1988]. Based on borehole failure observed in offshore wells between Icy Bay and Kayak Island Hottman et al. [1979] estimated the approximate magnitude of principal stresses. Their findings for depths between $2700 \mathrm{~m}$ and $4000 \mathrm{~m}$ were extrapolated to obtain estimates for the maximum $\sigma_{1}$ of about $65 \mathrm{MPa}$ and a minimum $\sigma_{3}$ of about $18 \mathrm{MPa}$ at a depth of $5 \mathrm{~km}$ [Sauber et al., 2000].

\section{Shear Failure and Fault Stability Criterion}

The state of stress in southern Alaska is considered to be the result of the superposition of the plate tectonic stresses, the stress due to overlying rocks, the pore fluid pressure, and the stress due to ice mass changes. In this section, we briefly discuss the fault failure criterion used to evaluate the influence of stress changes due to ice mass fluctuations.

\subsection{Mohr-Coulomb Failure Criterion}

The Mohr-Coulomb criterion for brittle shear failure in rock is described by 


$$
\tau=\tau_{0}+\mu \sigma_{\mathrm{n}}
$$

where $\tau$ is the shear stress necessary to induce failure on a fault plane, $\tau_{0}$ is the inherent shear strength of the fault, $\mu$ is the coefficient of friction of the fault surface, and $\sigma_{n}$ is the normal stress on the fault [Jaeger, 1969]. The locus of shear $\tau_{\mathrm{o}}$ and normal $\sigma_{\mathrm{n}}$ stress components on a suite of faults of various orientations is a Mohr circle whose center is the average between the maximum $\sigma_{1}$ and minimum $\sigma_{3}$ principal stresses and whose radius is $\left(\sigma_{1}-\sigma_{3}\right) / 2$ (Figure 3$)$.

\subsection{Fault Stability Margin}

Following the approach given in $W u$ and Hasegawa [1996], we estimated the fault stability margin and the change in that quantity due to ice mass changes (Figure 3). For a region in which the Mohr circle representing the stress state in southern Alaska is close to, but not in contact with the Coulomb failure envelope, we have the situation given in Figure 3. Here we assume that thrust faulting is the primary mode of crustal faulting as indicated above in Section 3. Since we are interested in the effect of glacial ice mass changes on faulting potential, we calculated the changes from an initial state $t_{o}$ until some time after glacial change, $t$. The shortest perpendicular distance from the failure envelope to the outer Mohr circle is defined at the Fault Stability Margin (FSM, in

Figure 3) and it is related to the principal compressive stresses by:

$$
\mathbf{F S M}=\beta\left[\mu\left(\sigma_{1}+\sigma_{3}\right)+2 \tau_{\mathrm{o}}\right]-1 / 2\left(\sigma_{1}-\sigma_{3}\right)
$$

(from $W u$ and Hasegawa 1996) where $\beta=[\arctan (\mu)] / 2 \mu$.

The variation of FSM (dFSM) will indicate whether ice mass loading will tend to trigger failure or promote stability: 


$$
\begin{aligned}
\operatorname{dFSM}= & 1 / 2\left\{\left[\sigma_{1}\left(\mathrm{t}_{\mathrm{o}}\right)-\sigma_{3}\left(\mathrm{t}_{\mathrm{o}}\right)\right]-\left[\sigma_{1}(\mathrm{t})-\sigma_{3}(\mathrm{t})\right]\right\}+ \\
& \mu \beta\left\{\left[\sigma_{1}(\mathrm{t})+\sigma_{3}(\mathrm{t})\right]-\left[\sigma_{1}\left(\mathrm{t}_{\mathrm{o}}\right)+\sigma_{3}\left(\mathrm{t}_{\mathrm{o}}\right)\right]\right\}
\end{aligned}
$$

Changes in the deviatoric stress or changes in the mean stress will move the Mohr circle. The first term (3a) represents the change in the mean stress associated with the stress change; the second term indicates the change in the deviatoric stress. Since we calculated the difference between an initial state and a later state, static pressure terms that affect all the principal stresses in the same way and do not vary in time, are automatically subtracted out. Thus, dFSM is independent of pore fluid pressure and the overburden stress for the lithostatic case [Wu and Hasegawa, 1996]. In the sections below we summarize our estimates of the surface displacements and stresses due to ice mass changes and we evaluated their influence on fault failure.

\section{Observed and Predicted Surface Displacement Rates and the Seismic Rate Associated with the Bering Glacier Surge Cycle}

The spatial (tens of kilometers) and temporal (1-2 years) scales, as well as the magnitude, of loading and unloading associated with the Bering Glacier surge cycle is similar to water reservoir impoundment and subsequent water level fluctuations. For loads of this spatial scale the response of the Earth is assumed to be primarily elastic or

poroelastic (see the summaries by Simpson et al., 1988; Scholz, 1990; Talwani, 1997). Since the stress increase from an elastic load drops off rapidly with distance, seismicity fluctuations in these cases are concentrated in the immediate vicinity of the load changes, and earthquake sizes tend to be small, since the stress gradients are high. In the following 
section we show the geodetic time series for two sites close to the Bering Glacier and we present the predicted contribution that ice fluctuations make to the observed station positions. Next, we examine the seismicity and seismic rate for portions of the intersurge, surge, and post-surge time periods. Here we tested the hypothesis that ice unloading promotes thrust-faulting earthquakes, whereas, ice loading inhibits thrustfaulting earthquakes.

\subsection{Observed and Predicted Surface Displacements}

As summarized in Section 2 a glacier that periodically surges undergoes a long period of slow build-up of ice in the middle and upper parts of the glacier with retreat in the terminus region. This is referred to as the intersurge in Figures 4-6. At some point this phase is followed by a surge where ice is rapidly transported from the surge reservoir region to the surge receiving region [Budd and McInnes, 1974; Bindschadler, 1982, Kamb et al., 1985].

The Bering Glacier's surge reservoir and receiving areas each have a geodetic site that was observed during the 1993 to 2000 time period. In Figure 4 the time series of station position is given for the North, East, and Up components for DON and ISLE. We assumed that the tectonic deformation rate was constant between 1993 and 2000. Earlier geodetic measurements at sites located $>20 \mathrm{~km}$ from areas of major ice mass fluctuations support this assumption [Ma et al., 1990; Sauber et al., 1993, 2000]. The departure from a constant rate of change, especially evident in the vertical component at DON and the east component of ISLE, is attributed to ice loading or unloading. We used the ice thickness changes between 1995 and 2000 summarized in Section 2 to calculate the 
predicted elastic displacement (Figure 5) following the approach given in Farrell [1972] and Sauber et al. [1995].

Station DON is located south of the Bering Glacier terminus and was observed in 1993, 1995, 1997, and 2000 (Figure 4a). The vertical component most dramatically demonstrates subsidence associated with ice loading of the ice receiving area in Bering Glacier's piedmont lobe, rapid uplift due to ice thinning and terminus retreat following the end of the surge (1995-1997), and then moderate uplift associated with continued ice thinning and terminus retreat (1997-2000). Due to an estimated, average thinning rate of $3.1 \mathrm{~m} / \mathrm{yr}$ across the ablation zone of the Bering Glacier between 1995 and 2000 [Arendt et al., 2002], station DON is predicted to move to the southeast (Figure 5a) and up (Figure $5 b)$. The predicted tectonic uplift rate is only $0-5 \mathrm{~mm} / \mathrm{yr}$ so the ice loading is especially evident; whereas the predicted horizontal tectonic rate is quite high (almost $40 \mathrm{~mm} / \mathrm{yr}$ to the north-northwest).

Station ISLE is located near the ice reservoir region in the Bagley Ice Valley and it was observed in 1993, 1995, and 2000 (Figure 4b). During the surge in 1993-1995, ice thinning in the adjacent Bagley Ice Valley caused ISLE to be displaced toward the northeast and up [Sauber et al., 1995, 2000]. Following the surge, some time between 1995 and 1998, the ice began to thicken in the Bagley Ice Valley but most of the Bering Glacier continued to thin. The combination of ice loading south of ISLE and the slower glacial wastage ice of surrounding glaciers caused ISLE to be displaced down slightly and to the east-southeast relative to the 1995 position (Figure 5). The predicted tectonic, vertical component is larger (about $12 \mathrm{~mm} / \mathrm{yr}$ ) than $\mathrm{DON}$, whereas the predicted horizontal component at ISLE is smaller than DON, about $20 \mathrm{~mm} / \mathrm{yr}$ to the north- 
northwest. As shown in Figure 2, the 1995-2000 horizontal velocity of ISLE is indeed more north directed than the surrounding station velocities which are oriented to the north-northwest.

\subsection{Seismicity and Seismic Rate}

In addition to surface displacement associated with ice mass changes, we hypothesize that with ice unloading thrust earthquakes would be promoted and with ice loading earthquakes would be inhibited. We plotted earthquakes of magnitude $\mathrm{M}_{\mathrm{L}} \geq 2.5$ between 1973-2003 (Figure 6). Included on the seismicity plots are three reference areas: (1) the surge reservoir region in Bagley Ice Valley near GPS site ISLE, (2) the lower portion of the Bering Glacier and the adjacent coastal plain that includes GPS site DON, and (3) the Cape Yakataga region where in the last 100 years only minor scale glacier fluctuations have occurred within $20 \mathrm{~km}$ of the VYAK. The Cape Yakataga region showed very few earthquakes throughout the 1973-2003 time period with the exception of a couple of earthquakes around the time of the 1979 St. Elias earthquake and one during the surge time interval (Figure 6).

For the Bagley Ice Valley (surge reservoir region), we examined the seismic rate for 4 time periods. For Jan. 1973 - Dec. 1992, following the 1967 surge and before the 1993 surge, thus "intersurge"; for Jan. 1993 - Dec. 1995, the "surge" time period; for Jan. 1996

- Dec. 1998, the" post-surge" readjustment period, and finally ice build-up in the reservoir region, "intersurge". In addition to examining the change in the number of earthquakes associated with stress changes [Stein, 1999], we calculated the cumulative seismic moment and the seismic moment rate because this quantity would be less sensitive to the detection threshold. Most of the earthquakes $\left(M_{L} \geq 2.5\right)$ in the reservoir 
region between 1973 and 2003 occurred during the surge time period or shortly afterwards in the post-surge time period (Figure 6). In addition to an increase in the number of earthquakes during the surge and post-surge time period, relative to the longer intersurge (1973-1992) time period, there was an order of magnitude increase in the seismic moment rate during the surge (Table 2).

Cumulative ice thinning in the reservoir region, during the surge, was on average $\sim 50$ meters across a $50 \mathrm{~km}$ region. For a short time following the surge, ice draw-down continued. The maximum dFSM associated with ice thinning during the surge was about $-0.5 \mathrm{MPa}$; the maximum change in the stress field would be at the surface in a localized region just below the ice thinning. However, at some time between 1996 and 1998 the ice began to thicken. From April 1998 to August 2003 no earthquakes $\left(M_{L} \geq 2.5\right)$ occurred in the surge reservoir box.

For the Bering Glacier terminus region (surge receiving area), there were few events. One event occurred during the early intersurge time period and one $\mathrm{M}_{\mathrm{L}}=4.3$ occurred during the later intersurge time period. During the intersurge time periods the Bering Glacier piedmont lobe undergoes terminus retreat as well as ice thinning. The one event during the surge time period occurred very early in April 1993 before the Bering Glacier terminus advanced during the surge. In the surge receiving area ice thickening and terminus advance (1993-1995) added an average of 50-100 meters of ice; the dFSM would be up to $1.0 \mathrm{MPa}$ and thrust earthquakes would be inhibited. Then, following five years of ice thinning and retreat after the surge, there was one event in $2001\left(\mathrm{M}_{\mathrm{L}}=4.3\right)$.

\section{Ice Mass Fluctuations and the Occurrence of Large Earthquakes}


Prior great earthquakes in the region given in Figure 1 occurred on September 4, 1899 $\left(\mathrm{M}_{\mathrm{w}}=8.1\right.$, Yakataga $)$ and September 10, $1899\left(\mathrm{M}_{\mathrm{w}}=8.1\right.$, Yakutat $)$ [Plafker and Thatcher, 1982; Nishenko and Jacob, 1990]. These events were large enough that they may have relieved much of the strain accumulation in the region referred to as the Yakataga seismic gap [Nishenko and Jacob, 1990]. The first event apparently was an interplate earthquake, which involved faulting along the Chugach-St. Elias fault zone. It produced coastal uplift of 1-3 m between Icy Cape (western mouth of Icy Bay) and Cape Yakataga (VYAK, in Figure 2) [Plafker and Thatcher, 1982; Jacoby and Ulan, 1983]. The second event caused massive uplift along the northwest shore of Yakutat Bay [Tarr and Martin, 1912].

The St. Elias earthquake of February 28, $1979\left(\mathrm{M}_{\mathrm{s}}=7.2\right)$, occurred on a down-dip extension of the Chugach-St. Elias fault system (Figures 1 and 2). Detailed modeling of seismic body and surface waves suggest a mainshock location to the northwest of Icy Bay (Figure 1) and an epicentral depth of $24 \mathrm{~km}$. A best-fitting source mechanism indicates initial underthrusting on a shallow north-dipping plane that later changed to a more steeply northeast dipping plane with a right-lateral component [Estabrook et al., 1992]. The ongoing tectonic strain accumulation across the region is shown in Figure 2 and discussed in Section 3. Next, we discuss the predicted viscoelastic response of the Earth to ice mass changes preceding the 1979 earthquake.

6.1 Changes in the Fault Stability Margin Prior to the 1979 St. Elias Earthquake

Since retreat of the Icy Bay glaciers started around the beginning of the twentieth century, we calculated the change in the fault stability margin associated with estimates of ice mass changes in the $\sim 80$ years prior to the 1979 earthquake. Earlier, Sauber et al. [2000] used a scaled, idealized profile of ice thickness change to calculate predicted 
surface displacements rates for comparison to a nearby geodetic site, AMBR (Figure 2). The results from that study suggest a preferred viscosity of $5 \times 10^{19} \mathrm{~Pa}$ s for depths $>38$ $\mathrm{km}$. Here we estimated ice thickness changes based on the data summarized in Section 2 . We estimated ice thickness changes along a profile extending from the western mouth of Icy Bay to the center of the aftershock zone (Figure 6). The estimated ice changes along this profile were $300-800$ meters in the coastal region and 100 meters southeast of the center of the aftershock zone. The average ice change value over a $10 \mathrm{~km}$ region was input as surface (node) force to the same viscoelastic finite element model used to estimate the tectonic contribution to surface deformation rates. The predicted surface displacements north of the maximum ice thickness change were upward and away from the trench (northwest, north, and northeast); whereas, just south of the region of maximum ice change, surface displacements were directed upward and toward the southwest, south, and southeast (Figure 5).

The change in the fault stability margin (dFSM) was calculated on the surface and at depth along the main thrust zone. We calculated dFSM in two different ways. In the first case we assumed an initial stress state of zero following the 1899 earthquakes. In the second case we assumed the stress magnitudes given for a depth of $5 \mathrm{~km}$ (discussed in Section 3) as an initial state. As expected the dFSM was the same in both cases. The dFSM due to the elastic response to ice mass changes was the largest component in the viscoelastic response. The dFSM due to total ice changes over $\sim 80$ years were up -3.6 $\mathrm{MPa}$ at the surface and $-2.2 \mathrm{MPa}$ along the main thrust zone. The largest change occurs in the region just north of the maximum ice thickness change where the maximum increase to $\sigma_{1}$ as well as a decrease in $\sigma_{3}$, the vertical stress, occurs. These changes 
increase the size of Mohr circle, bringing the region closer to failure (Figure 3). The location of dense earthquake occurrence associated with the 1979 event (Figure 6) is north of the region of large ice thickness change.

\section{Discussion and Summary}

The large glacier ice mass changes associated with glacial wastage and surges perturb the tectonic rate of deformation at a variety of temporal and spatial scales. We estimated surface displacements and stresses associated with ice mass fluctuations and tectonic loading by examining GPS geodetic observations and numerical model predictions. Although the glacial fluctuations perturb the tectonic stress field, especially at shallow depths, the largest contribution to ongoing crustal deformation is horizontal tectonic strain due to plate convergence. Tectonic forces are thus the primary force responsible for major earthquakes. However, for geodetic sites located $<10-20 \mathrm{~km}$ from major ice mass fluctuations, the changes of the solid Earth due to ice loading and unloading are an important aspect of interpreting geodetic results.

The ice changes associated with Bering Glacier's most recent surge cycle are large enough to cause discernible surface displacements. Additionally, ice mass fluctuations associated with the surge cycle can modify the short-term seismicity rates in a local region. For the thrust faulting environment of the study region a large decrease in ice load may cause an increase in seismic rate in a region close to failure whereas ice loading may inhibit thrust faulting. We did not observe a change in the seismicity rate associated with smaller seasonal ice mass fluctuations (i.e. late summer versus late winter). 
Prior to the 1979 St. Elias earthquake, the main thrust zone below Icy Bay had been locked since the 1899 earthquakes and strain had been accumulating. During this same time period ongoing wastage of southern Alaska glaciers was 100's of meters up to almost a $1 \mathrm{~km}$. We used estimates of ice thickness decrease to calculate the changes in the fault stability margin around the region of the 1979 St. Elias earthquake and aftershocks. Our results suggest that the cumulative decrease in the fault stability margin due to ice wastage between 1899 and 1979 was large and would promote thrust faulting. Since earthquake hazard evaluations are based on the paleoseismic history of the region, for glaciated areas the concurrent glacial history should be considered in this evaluation.

Acknowledgements. We thank John Tucker and Jim Long for their heroic efforts in obtaining GPS observations in the Bagley Ice Valley in August 2000; Bob King, Tom Herring and Simon McClusky for GAMIT and GLOBK help; Steve Cohen for discussions on finite element modeling; George Plafker for discussions on the earthquake history in the Yakataga region. We thank Dennis Trabant, Tom James, and an anonymous reviewer for their constructive suggestions and careful reviews of an earlier draft. This research was supported by grants to J. Sauber from NASA's ICESat project and the Solid Earth and Natural Hazards programan $\$$ by the Earth Surface Processes Program of the USGS to B. Molnia. 


\section{References}

Arendt, A. A., K. A. Echelmeyer, W. D. Harrison, C. S. Lingle, V. B. Valentine, 2002, Rapid wastage of Alaska Glaciers and their contribution to rising sea level, Science, 297, $382-386$.

Bindschadler, R., 1982, A numerical model of temperate glacier flow applied to the quiescent phase of a surge-type glacier, J. of Glaciology, 28(99), 239-265.

Budd, W.F., and B.J. McInnes, 1974, Modeling periodically surging glaciers, Science, $186,925-927$.

Cohen, S.C., 1996, Time-dependent uplift of the Kenai Peninsula and adjacent regions of south central Alaska since the 1964 Prince William Sound earthquake, J. Geophys. Res., $101,8595-8604$.

DeMets, C., R. G. Gordon, D. Argus, and S. Stein, 1994, Effect of recent revisions to the geomagnetic reversal time scale on estimates of current plate motions, Geophys. Res., Lett., 21, 2191-2194.

Doser, D. I., J. R. Pelton, and A. M. Veilleux, 1997, Earthquakes in the Pamplona zone, Yakutat block, south central Alaska, J. Geophys.Res., 102, 24,499-24,511. 
Estabrook, C. H., J. L. Nabelek, A. L. Lerner-Lam, 1992, Tectonic model of the PacificNorth American plate boundary in the Gulf of Alaska from broadband analysis of the 1979 St. Elias, Alaska, earthquake and its aftershocks, J. Geophys. Res. 97(B5), $6587-$ 6612.

Farrell, W. E., 1992, Deformation of the Earth by surface loads, Rev. Geophys., 10, 761797.

Fatland, D. R., 1998, Studies of Bagley Ice Field during surge and Black Rapids Glacier, Alaska, using spaceborne SAR interferometry, Ph.D. Thesis, 97 pp., Univ. of Alas. Fairbanks, Dec.

Fatland, D. R., and C. S. Lingle, 1998, Analysis of the 1993-95 Bering Glacier surge using differential SAR interferometry, J. Glaciol., 44, 532-546.

Hamilton, T. D., 1994, Late Cenozoic glaciation of Alaska, in The Geology of North America, vol. G-1, The Geology of Alaska, eds. G. Plafker and H. C. Berg, pp. 813-844, Boulder, Colo.

Herring, T. A., 1997, GLOBK, Global Kalman filter VLBI and GPS analysis program version 4.1, Mass. Inst. of Technol., Cambridge. 
Herzfeld, U. C., and H. Mayer, 1997, Surge of Bering Glacier and Bagley Ice Field, Alaska: an update to August 1995 and an interpretation of brittle deformation patterns, J. Glaciol., 143, 427-434.

Hottman, C. E., J. H. Smith, and W. R. Purcell, 1979, Relationship among Earth stresses, pore pressure, and drilling problems offshore Gulf of Alaska, J. Pet. Technol., 31, 14771484.

Hwang, L. I., and H. Kanamori, 1992, Rupture processes of the 1987-1988 Gulf of Alaska earthquake sequence, J. Geophys. Res.,97, 19,881-19,908.

Ivins, E. R., and T. S. James, 1999, Simple models for late Holocene and present-day Patagonian glacier fluctuations and predictions for a geodetically detectable isostatic response, J. Geophys. Res., 138, 602-624.

Jacoby, G. C., and L. D. Ulan, 1983, Tree ring indications of uplift at Icy Cape, Alaska, related to the 1899 earthquakes, J. Geophys. Res., 88(B11), 9305-9313.

Jaeger, J. C., 1969, Elasticity, Fracture, and Flow in Engineering and Geological Applications, 268pp., Methuen, New York. 
Jaeger, J., B. Hallet, T. Pavlis, J. Sauber, D. Lawson, J. Milliman, R. Powell, S. P. Anderson, and R. Anderson, 2001, Orogenic and glacial research in pristine southern Alaska, Eos, Trans. Am. Geophys. Union, 82(19), 213,216.

James, T. S., J. J. Clague, K. Wang, and I. Hutchinson, 2000, Postglacial rebound at the northern Cascadia subduction zone, eds. I. S. Stewart, J. Sauber, and J. Rose, Quaternary Science Reviews, Glacio-seismotectonics: Ice Sheets, Crustal Deformation and Seismicity, 19(14-15), 1527-1542.

Kamb, B., C.F. Raymond, W.D. Harrison, H. Engelhardt, K.A. Echelmeyer, N. Humphrey, M.M. Brugman, and T. Pfeffer, 1985, Glacier surge mechanism: 1982-1983 surge of Variegated Glacier, Alaska, Science, 227(4686), 469-479.

King, R. W., and Y. Bock, 1997, Documentation for the GAMIT GPS analysis software: GAMIT, version 9.6, Mass. Inst. of Technol., Cambridge.

Krimmel, R. M., 1994, Photogrammetric measurement of geometric changes of Bering Glacier during the 1993-94 surge (abstract), Eos Trans. AGU, 75(44), Fall Meet. Suppl., 62.

Larsen, C., J. Freymueller, K. Echelmeyer, R. Motyka, and E. Ivins, 2003, Rapid uplift in SE Alaska caused by past and present glacial unloading, Geophys. Res. Abstracts, European Geophys. Soc., Vol. 5, 13846. 
Lingle, C. S., A. Post, U. C. Herzfeld, B. F. Molnia, R. M. Krimmel, and J. J. Roush, 1993, Bering Glacier surge and iceberg-calving mechanism at Vitus Lake, Alaska, U.S.A., J. Glaciol., 39, 722-727.

Lingle, C. S., K.A. Echelmeyer, W. A. Seider, H. Li, and V. B. Valentine, 1999, A new estimate of elevation and volume changes on Seward and Malaspina Glaciers, southcentral Alaska and Yukon, from small-aircraft laser altimetry, ERS SAR imagery, and the 15 minute DEM of Alaska: Eos Trans. AGU, 80-46, Fall Meeting Supplement, p. F355.

Ma, C., J. M. Sauber, L.J. Bell, T.A. Clark, D. Gordon, W.E. Himwich, and J.W. Ryan, 1990, Measurement of horizontal motions in Alaska using very long baseline interferometry, J. Geophys. Res., 21991-22011.

Melosh, H. J., and A. Raefsky, 1981, A simple and efficient method for introducing faults into finite element computations, Bull. Seismol. Soc. Am., 71, 1391-1400.

Molnia, B.F., 1977, Rapid shoreline erosion and retreat at Icy Bay Alaska - a staging area for offshore petroleum development: Proceedings of the $9^{\text {th }}$ Annual Offshore Technology Conference, 115-126. 
Molnia, B. F., 1989, Subartic (temperate) glacial-marine sedimentation-The northeast Gulf of Alaska, eds. J. B. Andersen and B. F. Molnia, Glacial-Marine sedimentation, $28^{\text {th }}$ International Geological Congress, Short Course, Geol. Ser., vol. 9, pp. 59-106, AGU, Washington, D.C.

Molnia, B. F., 1993, Major surge of the Bering Glacier, Eos Trans. AGU, 74, 321-322.

Molnia, B. F., 2003, Glaciers of Alaska, with chapters on Tidewater Glaciers by R. M. Krimmel; and the 1986 and 2002 Closures of Russell Fiord by B.F. Molnia, D. C. Trabant, and R. S. Marsh; in Williams, R. S. J., and Ferrigno, J. G., eds., Satellite Image Atlas of Glaciers of the World; Glaciers of the United States, U.S. Geological Survey Professional Paper 1386-K, 750 p., in press.

Molnia, B. F., and A. Post, 1995, Holocene history of Bering Glacier, Alaska: A prelude to the 1993-1994 surge, Phys. Geogr., 16, 87-117.

Molnia, B. F., A. Post, D. C. Trabant, and R. M. Krimmel, 1994, The 1993-94 surge of Bering Glacier, Alaska: An overview (abstract), Eos Trans. AGU, 75(44), Fall Meet. Supple., 62.

Muller, E. H., and P. J. Fleisher, 1995, Surging history and potential for renewed retreat: Bering Glacier, Alaska, U.S.A., Arct. Alp. Res., 27, 81-88. 
Nishenko, S. P., and K. H. Jacob, 1990, Seismic potential of the Queen Charlotte-AlaskaAleutian seismic zone, J. of Geophys. Res. 95(B3), 2511-2532.

Peltier, W. R., 1993, Time dependent topography through glacial cycle, IGBP PAGES/Cent.A for Paleoclimatol. Data Contrib. Ser. 93-015, NOAA/NGDC Paleoclimatol. Program, Boulder, Colo.

Peltier, W. R., 1994, Ice age paleotopography, Science, 265, 195-201.

Plafker, G., and W. Thatcher, 1982, Geological and geophysical evaluation of the great 1899-1900 Yakutat Bay, Alaska earthquakes (abstract), paper presented at AGU Chapman Conference on Fault Behavior and the Earthquake Generation Process, AGU, Snowbird, Utah, Oct. 11-15.

Plafker, G., T. Hudson, M. Rubin, and K. L. Dixon, 1981, Holocene marine terraces and uplift history in the Yakataga seismic gap near Icy Cape, Alaska, U.S. Geol. Surv. Circ., $844,111-115$.

Plafker, G., L. M. Gilpin, and J. C. Lahr, 1994, Neotectonic map of Alaska, scale 1:2,500,000, in Geology of Alaska, Map, GNA-G-1, Plate 12a, Geol. Soc. of Am., Boulder, Colo. 
Porter, S.C., 1989, Late Holocene fluctuations of the fiord glacier system in Icy Bay, Alaska, USA: Arctic and Alpine Research, 364-379.

Porter, S. C., and G. H. Denton, 1967, Chronology of neoglaciation in the North American Cordillera, Am. J. of Science, 265, 177-210, 83-256, 1 sheet.

Roush, J.J., 1996, The 1993-1994 surge of Bering Glacier, Alaska, observed with satellite synthetic aperture radar, M.S. thesis, Univ. of Alas., Fairbanks.

Sauber, J., T. A. Clark, L. J. Bell, M. Lisowski, C. Ma, and D. S. Caprette, 1993, Geodetic measurement of static displacement associated with the 1987-1988 Gulf of Alaska earthquakes, eds. D.E. Smith and D. L. Turcotte, Contributions of Space Geodesy to Geodynamics: Crustal Dynamics, Geodynamics 23, 233-248.

Sauber, J., G. Plafker, J. Gibson, 1995, Geodetic measurements used to estimate ice transfer during Bering Glacier surge, Eos, Trans. AGU, 76(29), July 18.

Sauber, J., S. McClusky, and R. King, 1997, Relation of ongoing deformation rates to the subduction process in southern Alaska, Geophys. Res. Lett., 24, 2853-2856.

Sauber, J., G. Plafker, B. F. Molnia, and M.A. Bryant, 2000, Crustal deformation associated with glacial fluctuations in the eastern Chugach Mountains, Alaska, J. Geophys. Res., 105, 8055-8077. 
Sauber, J., T. Pavlis, and R. King, 2002, Crustal deformation rates and mountain building in southern Alaska, EGS02-A-01778, European Geophys. Soc. XXVII General Assembly.

Savage, J.C., and M. Lisowski, 1988, Deformation in the Yakataga seismic gap, southern Alaska, 1980-1986, J. Geophys. Res., 93, 4731-4744.

Scholz, C. H., 1990, The Mechanics of Earthquakes and Faulting, pp. 324-333, Cambridge Univ. Press, New York.

Sharp, R.P., 1961, Accumulation and ablation on the Seward-Malaspina Glacier system, Canada-Alaska: Bulletin of the Geological Society of America, 62, 725-744.

Simpson, D. W., W. S. Leith, and C. H. Scholz, 1988, Two types of reservoir induced seismicity, Bull. Seism. Soc. Am., 78, 2025-2040.

Stein, R. S., 1999, The role of stress transfer in earthquake occurrence, Nature, 402, 605609.

Stewart, I. S., J. Sauber, and J. Rose, 2000, Glacio-seismotectonics: Ice Sheets, Crustal Deformation and Seismicity, Topical Issue, eds. I.S. Stewart, J. Sauber and J. Rose, Quaternary Science Reviews, , Vol. 19(14-15), 1367-1389. 
Talwani, P., 1997, On the nature of reservoir-induced seismicity, Pageoph., 150, 473-492.

Tamisiea, M. E., J. X. Mitrovica, J. L. Davis, 2003, A method of detecting rapid mass flux of small glaciers using local sea level variations, Earth and Planetary Science Letters, 213, 477-485.

Tangborn, W. V., 1999, A mass balance model that uses low-altitude meteorological observations and the area-altitude distribution of a glacier, Geografiska Annaler, 81A, 753-765.

Tarr, R. S., and L. Martin, 1912, The earthquakes at Yakutat Bay, Alaska, in September, 1899, U.S. Geol. Soc. Prof. Pap., 69.

United States Geological Survey, 1983, Bering Glacier, Alaska, 1:250,000-scale topographic map, 1 sheet, 1959, minor revisions in 1983.

Wu, P. and H. S. Hasegawa, 1996, Induced stresses and fault potential in eastern Canada due to a disc load: a preliminary analysis, J. Geophys. Int., 125, 415-430. 


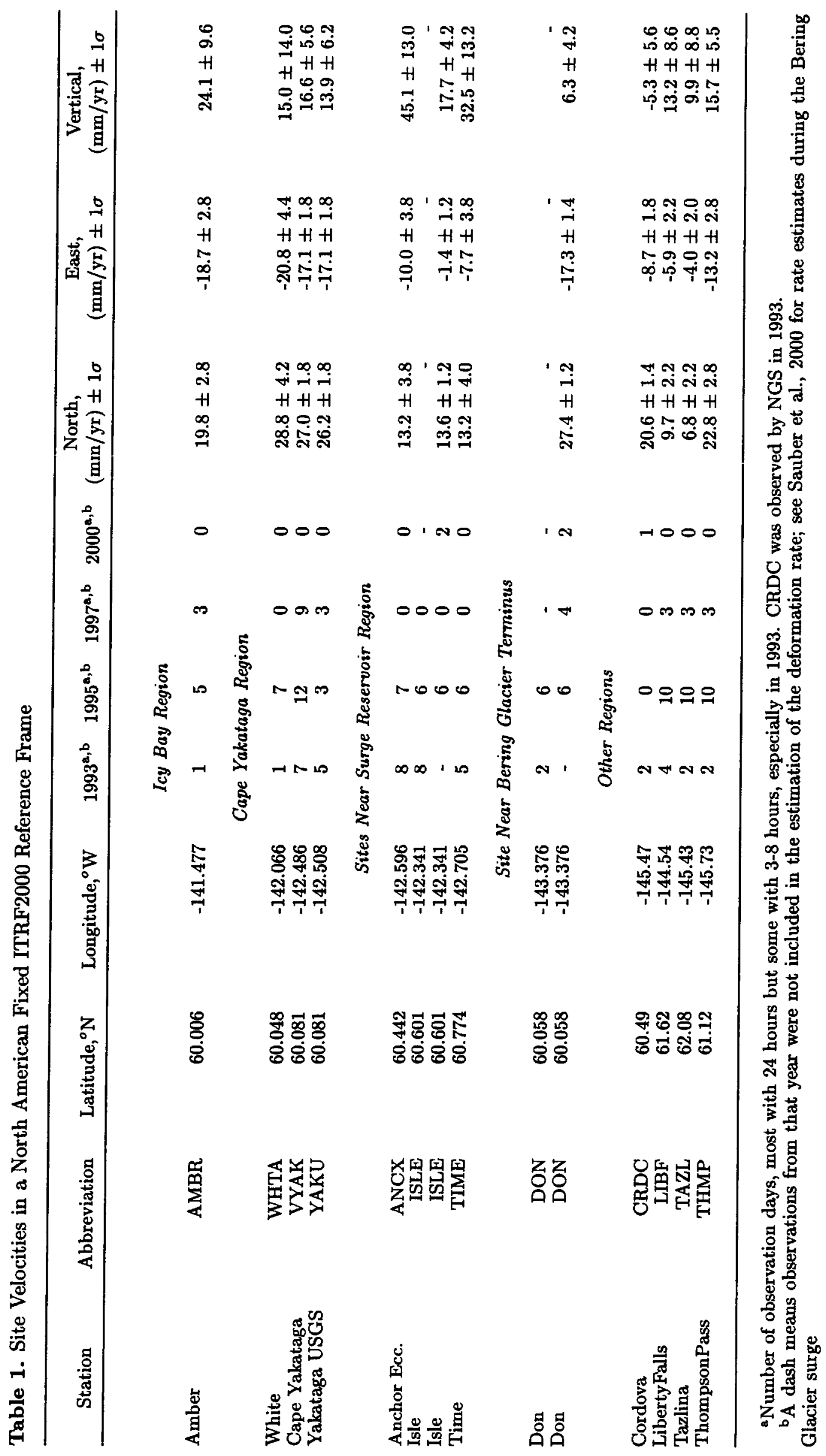


Table 2. Earthquakes and Seismic Moment Rate as a Function of Time in the Bering Glacier's Surge Reservoir Region

Date

Jan. 1973-Dec.1992 2

Jan.1993-Dec.1995 7

Jan.1996-Dec.1998 3

Jan. 1999-Aug. $2003 \quad 0$
Seismic Moment

(dyne- $\mathrm{cm}$ )

$2.4 \times 10^{21}$

$2.2 \times 10^{22}$

$3.5 \times 10^{20}$
Seismic Moment Rate (dyne-cm/yr)

$1.2 \times 10^{20}$

$7.3 \times 10^{21}$

$1.1 \times 10^{20}$ 


\section{Figure Captions}

Figure 1. The August 9, 2003 true color, Moderate Resolution Imaging Spectroradiometer (MODIS) image from NASA's Aqua satellite of the southern Alaska coastal region. The MODIS image shows the Malaspina piedmont lobe in the east and the Bering piedmont lobe in the west. The solid star shows the location of the $1979 \mathrm{St}$. Elias epicenter. The image is courtesy of the MODIS Rapid Response Project at NASA/GSFC. The inset in the lower left hand corner shows the region of Alaska covered by Figure 1 .

Figure 2. Location of geodetic sites occupied between 1993 and 2000 in which the horizontal velocities have been estimated (solid circle with site abbreviations from Table 1). The vector velocities of sites relative to an ITRF2000 North America fixed reference frame are given with error ellipses representing regions of $95 \%$ confidence. The shaded regions (with year) indicate the rupture zones of major earthquakes in southern Alaska during the twentieth century. The NUVEL-1A predicted, horizontal velocity of the Pacific plate relative to a fixed North American plate $\left(52 \mathrm{~mm} / \mathrm{yr}\right.$ at $\mathrm{N} 14^{\circ} \mathrm{W}$, DeMets et al., 1994) is shown by the vector in the lower right hand corner. Faults (solid lines): BRF $=$ Border Ranges, $\mathrm{CF}=$ Contact, $\mathrm{CSEF}=$ Chugach-St. Elias, $\mathrm{DF}=$ Denali, $\mathrm{FF}=$ Fairweather, $\mathrm{PFZ}=$ Pamplona fault zone $\mathrm{TF}=$ Totschunda, $\mathrm{TFZ}=$ Transition, ${ }^{*} \mathrm{MW}=$ Mount Wrangell, the youngest volcano in the western Wrangell volcanic zone. The dotted line indicates the region given in Figure 1. 
Figure 3. Mohr circle, Coulomb failure line, Fault Stability Margin (FSM) and thrust faulting mode (modified from $W u$ and Hasegawa, 1996). The stress state is defined by the principal (compressive) stress components: the maximum principal stress $\sigma_{1}$, the intermediate principal stress $\left(\sigma_{2}\right)$, and a minimum effective stress $\sigma_{3}$. For the thrust faulting mode considered here, the maximum $\left(\sigma_{1}\right)$ and intermediate principal stress $\left(\sigma_{2}\right)$ are horizontal and the least principal stress is vertical $\left(\sigma_{3}\right)$.

Figure 4. North, east, and vertical station position evolution for the station DON (a) and ISLE (b). The station positions for both sites are predictcd to move to the northwest and up due to tectonic forcing. For the 1993-1995 surge interval, the predicted influence of ice unloading near ISLE and ice loading near DON are given by Figure 2 and Plate 1 in Sauber et al. [2000]. For the 1995-2000 post-surge time interval, the predicted influence of ice changes from section 2 of this paper is given in Figure 5a,b.

Figure 5. Predicted displacement of the solid Earth due to ice changes between 1995 and 2000 represented by disk loads. (a) Predicted horizontal elastic displacement field (millimeters) of the solid Earth due to ice thinning and retreat in the ablation zone of the Bering Glacier (red disks) and ice loading in the Bagley Ice Valley (blue disks). The value in meters from the bottom left to the top right: $-20,-20,-20,-20,-20,-20,-20,-20$, $-20,-20,-20,-20,-20,-15,-15,-15,-15,-15,-15,-15,-15,-15,-15,-15,-15,-10,-10,-$ $10,-10,-5,-5,-5,-5,-5,-5,-5,-5,-5,-5,-5,-5,-5,-5,-5,-5,-5,10,20,20,20,20,20$, $20,20,-5,-5,-5,-5,-5,-5,-5,-5,-5,-5 . \quad$ (b) A contour plot of the predicted uplift and 
subsidence (millimeters) of the solid Earth associated with the loading/unloading given in Figure 5a.

Figure 6. Earthquakes of $\mathrm{M}_{\mathrm{L}} \geq 2.5$ between $59^{\circ} \mathrm{N}$ and $61^{\circ} \mathrm{N}$ and $139^{\circ} \mathrm{W}$ and $144^{\circ} \mathrm{W}$ between 1973 and 2003. The long-dashed rectangles indicate the surge reservoir in the Bagley Ice Valley and the surge receiving area of the Bering Glacier terminus; the short dashed line indicates the Cape Yakataga rectangle. Fault abbreviations are as given in Figure 2. GPS stations are given by open squares. 









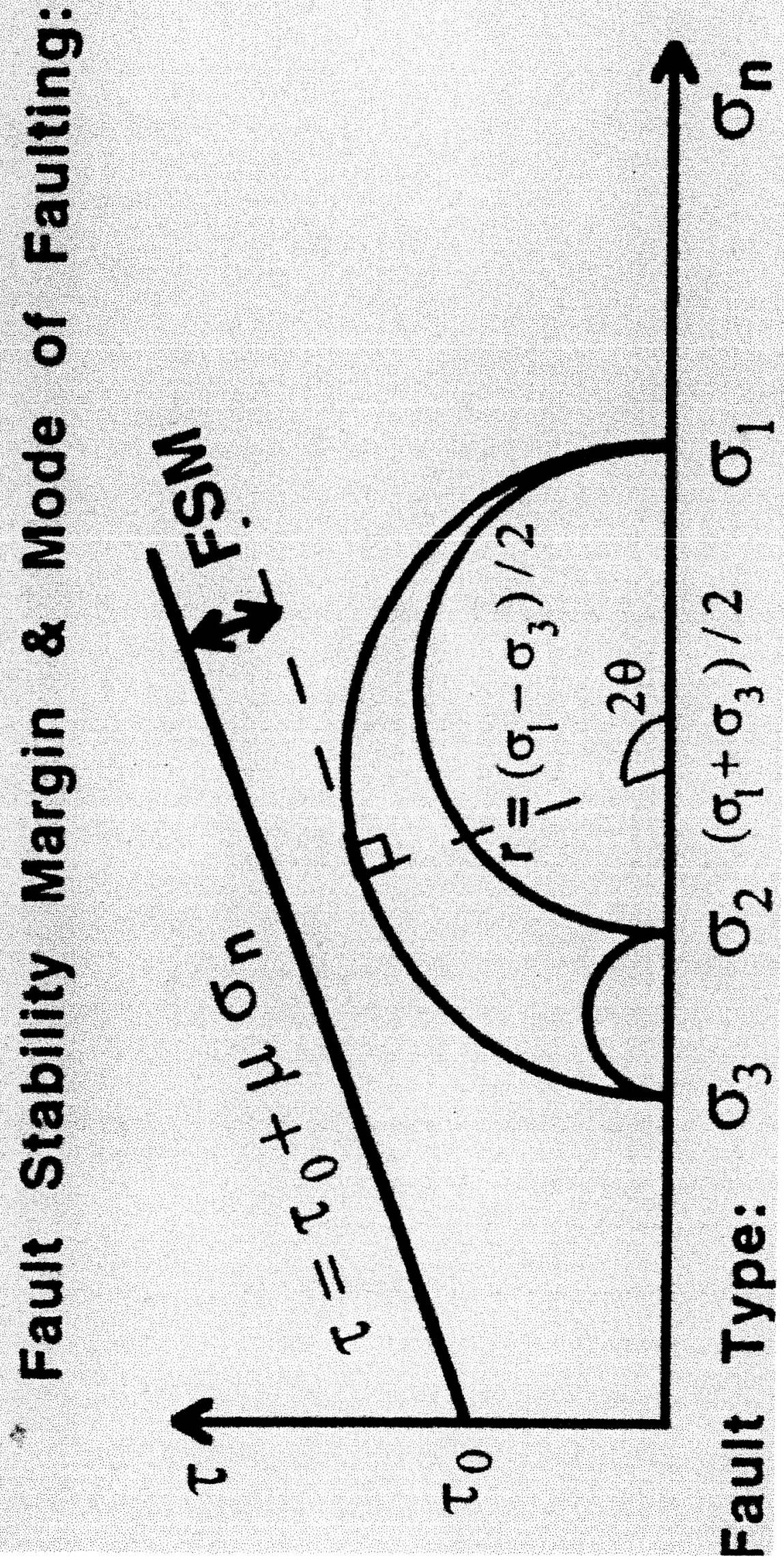



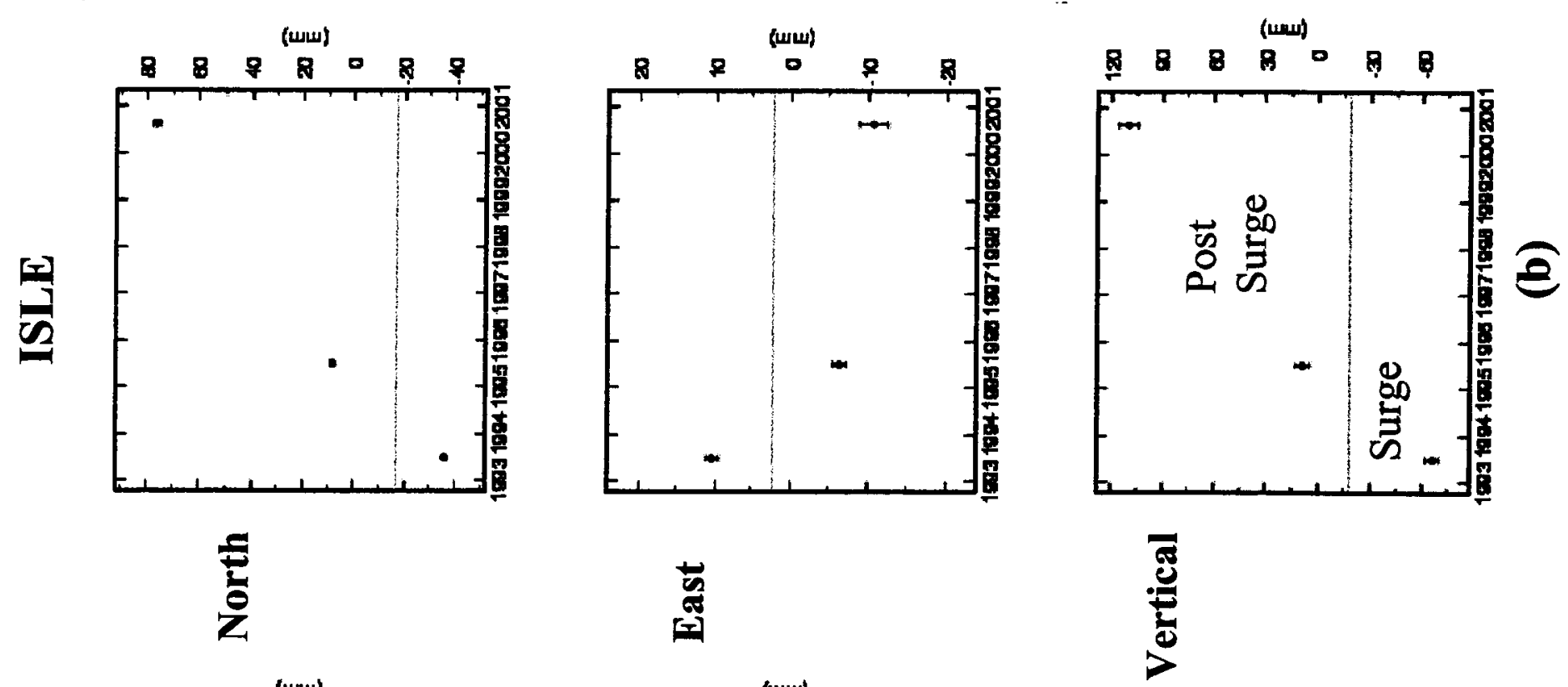

$x$



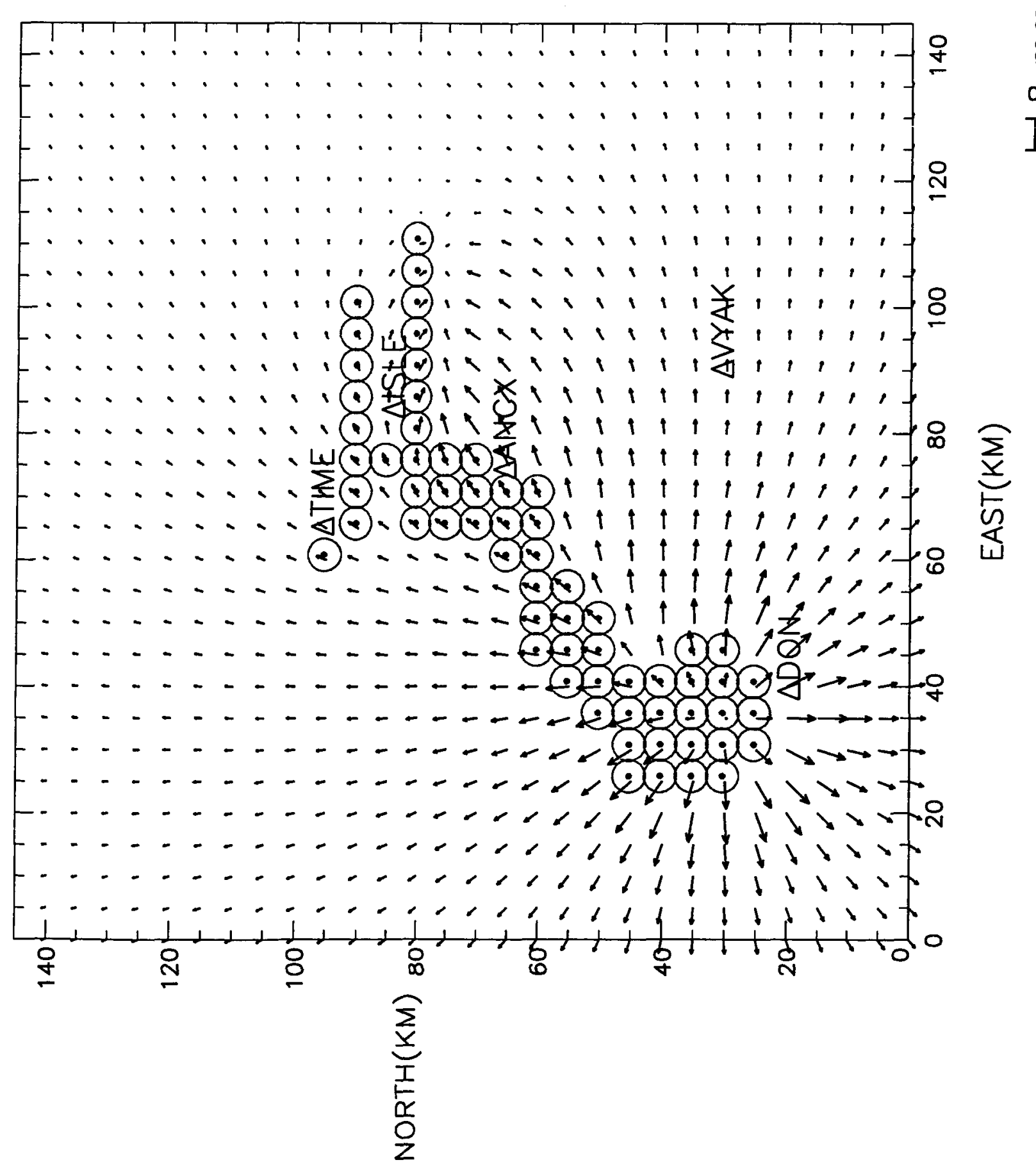




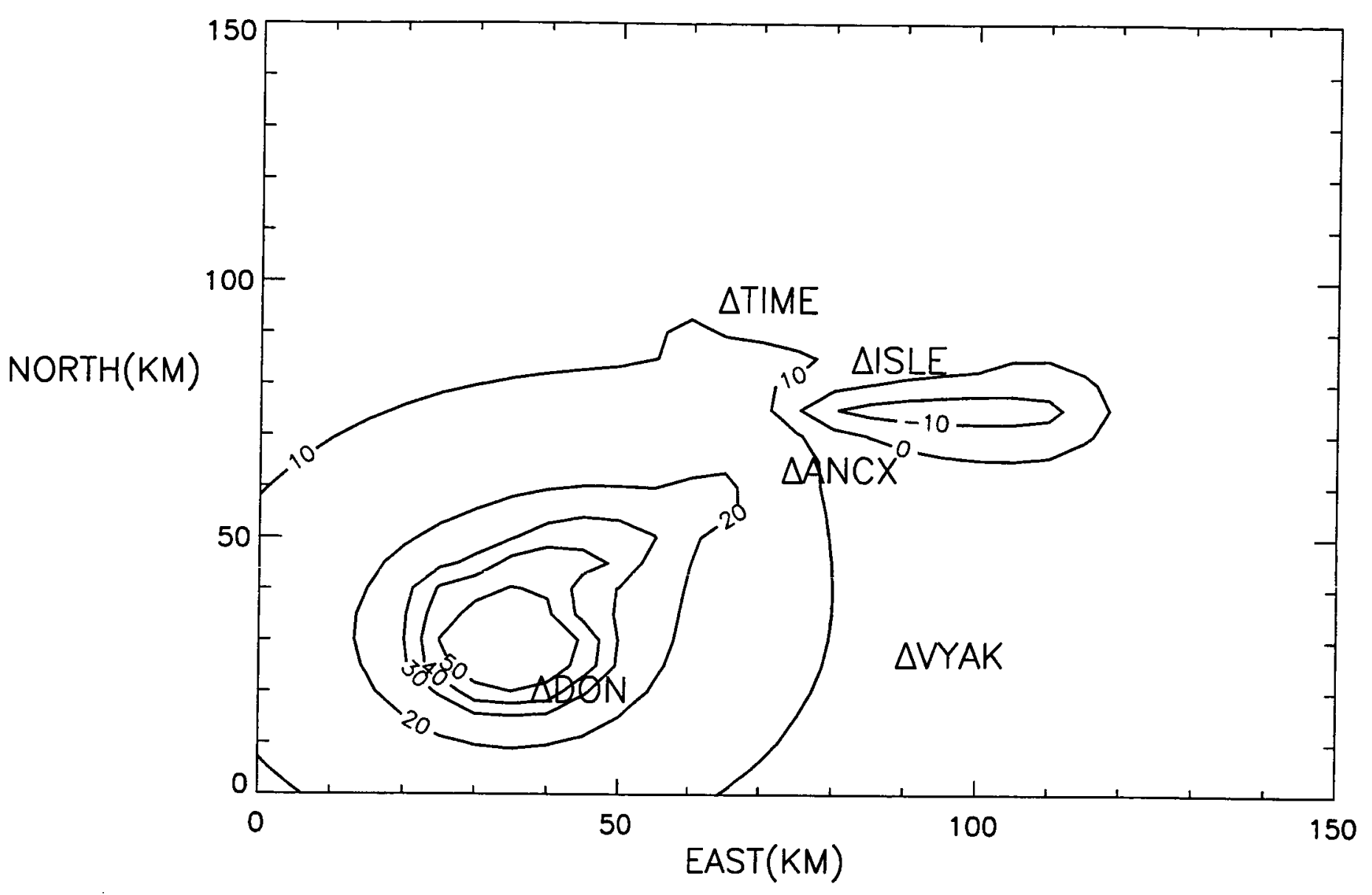

Fig $5 b$ 


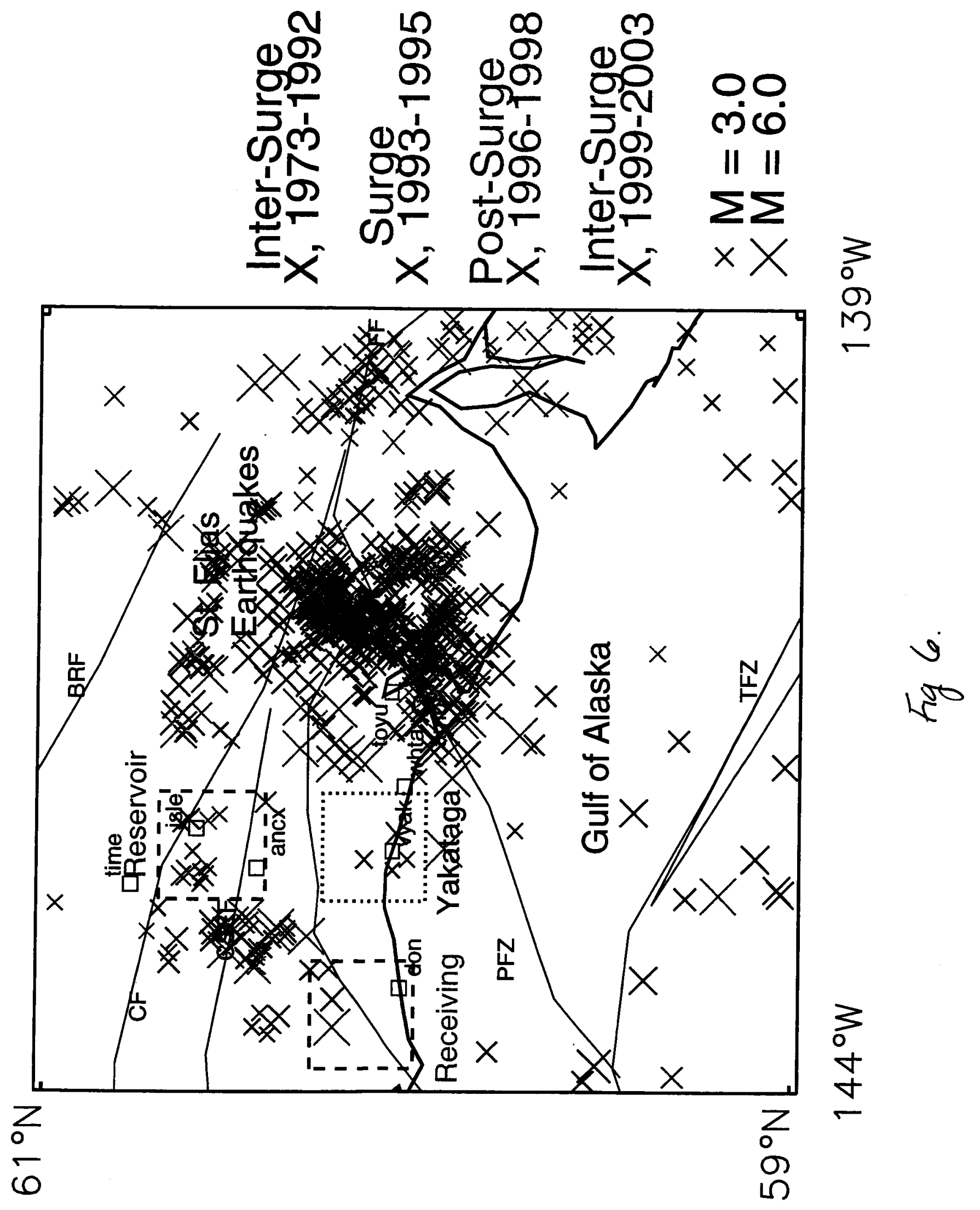

